\title{
Evaluation of the combined addition of aluminum lactate and calcium carbonate to alumina-based castables
}

\author{
L. B. Consonni ${ }^{1 *}$, A. P. da Luz ${ }^{1}$, V. C. Pandolfelli ${ }^{1}$ \\ ${ }^{I}$ Federal University of Sao Carlos, Graduate Program in Materials Science and Engineering, Rod. Washington \\ Luís, km 235, 13565-905, São Carlos, SP, Brazil
}

\begin{abstract}
Calcium aluminate cement (CAC) can induce the development of high green mechanical strength to refractory castables in a short period of time $(24 \mathrm{~h})$. However, the production of this hydraulic binder is energy-intensive and releases a large content of carbon dioxide $\left(\mathrm{CO}_{2}\right)$, which adds to global warming. Thus, aiming to develop an alternative binding system, this study investigated the combined addition of aluminum lactate $(0.25-1.0 \mathrm{wt} \%)$ and calcium carbonate $(3.2 \mathrm{wt} \%)$ to alumina castables. The prepared samples were analyzed using different experimental techniques, such as cold and hot modulus of rupture, hot elastic modulus, X-ray diffraction, and apparent porosity. According to the results, the lactate addition to the castables improved their green mechanical strength after drying at $110{ }^{\circ} \mathrm{C} / 24 \mathrm{~h}(4.89 \mathrm{MPa})$ when compared to the one containing plain calcium carbonate (1.72 $\mathrm{MPa})$. Furthermore, the carbonate-containing refractories presented cold and hot modulus of rupture similar or even superior to the castable containing cement in a wide temperature range $\left(600-1500{ }^{\circ} \mathrm{C}\right)$.
\end{abstract}

Keywords: alumina, refractory castables, sintering, calcium aluminate cement, calcium carbonate, aluminum lactate.

\section{INTRODUCTION}

In the last 30 years, there have been global efforts aiming to mitigate climate change, as it was attempted with the Kyoto Protocol in the 1990s and with the Paris Agreement in the 2000s. Those initiatives have been focused on lowering greenhouse gas emissions, such as carbon dioxide $\left(\mathrm{CO}_{2}\right)$, which arises mainly from energy consumption [1,2]. Regarding this matter, the industrial sector consumes $37 \%$ of the world's total delivered energy, and heavy industries like aluminum, iron, and steel producers are responsible for a great part of it [3]. As they operate at high temperatures, there is a great thermal energy consumption to heat the vessels that contain the molten metal and also in the first thermal treatment of the refractory ceramics that are placed as lining in these vessels. In order to increase the energy efficiency of these heavy industries, it is interesting to develop refractories that can be fired at lower temperatures and/or for shorter periods of time. Refractory castables have somehow contributed to this energy efficiency in recent decades due to their easier installation and better performance when compared to bricks and shaped refractories $[4,5]$. However, using calcium aluminate cement (CAC) as a hydraulic binder for these ceramic systems has hindered further improvements of the refractory castables. Although this binder provides high green mechanical strength in a short period of time $(24 \mathrm{~h})$, its production involves the reaction at high temperatures $\left(>1000^{\circ} \mathrm{C}\right)$ of calcium carbonate $\left(\mathrm{CaCO}_{3}\right)$ and alumina $\left(\mathrm{Al}_{2} \mathrm{O}_{3}\right)$, a process that is energy-intensive and releases a large amount of carbon dioxide [6]. Furthermore,

*leoconsoni@gmail.com

Dhttps://orcid.org/0000-0003-3688-6010 cement provides densification of the refractories only above $1200{ }^{\circ} \mathrm{C}[7]$, restricting the best mechanical properties to this temperature range and inhibiting the firing of these materials at lower temperatures. Thus, it is relevant to evaluate other raw materials that could replace this binder in refractories.

In this sense, the direct use of calcium carbonate would be an alternative as it would eliminate the energy-intensive process of production of $\mathrm{CAC}$ and because it can generate the same calcium aluminate phases above $1000{ }^{\circ} \mathrm{C}\left(\mathrm{CA}_{2}\right.$ and $\mathrm{CA}_{6}$, where $\mathrm{C}=\mathrm{CaO}$ and $\mathrm{A}=\mathrm{Al}_{2} \mathrm{O}_{3}$ [8-10]). Luz et al. [11] reported that using calcium carbonate in alumina-based dense refractories resulted in a sintering effect that decreased the strengthening onset temperature to the $600-1000{ }^{\circ} \mathrm{C}$ range. This effect was not associated with the decomposition of calcium carbonate, but with a sintering-coarsening-coalescence (SCC) phenomenon previously investigated by Lin and Shen [12]. These authors identified a decrease in the specific surface area of fine $\mathrm{CaCO}_{3}$ particles around $450-600{ }^{\circ} \mathrm{C}$, and the physical changes that induced this phenomenon were related to two main mechanisms: i) solid-state sintering derived from atom diffusion along the grain boundaries, and ii) coarsening and coalescence of the particles due to their re-packing. Some studies $[10,11]$ evaluating high-alumina $\mathrm{CaCO}_{3}$ bonded castables pointed out the development of greater cold and hot mechanical strength values for such materials when compared to similar compositions containing CAC. However, Luz et al. [11] identified a lack of effective binding action of calcium carbonate at low temperatures, resulting in samples with low green mechanical strength after curing and drying. Considering these aspects, a literature survey for additives that could induce a binding effect for alumina refractory castables containing calcium carbonate has been made. It was found out that the addition of aluminum lactate 
to high-alumina magnesia-bonded castables helped to inhibit the samples' explosion during drying and increased their green mechanical strength [13, 14]. Moreover, some studies $[15,16]$ reported a sol-gel aluminum lactate route to produce alumina glass, investigating the $\mathrm{pH}$ 's effect over the hydrolysis and gelation of this organic salt. Through solidstate nuclear magnetic resonance (NMR), those authors reported that gelation could be favored for compositions with $\mathrm{pH}$ between 3 to 10 and, outside this range, the aluminum octahedral complex $\left[(\mathrm{R}-\mathrm{COO})_{3} \mathrm{Al}\right.$, Fig. 1] was fully hydrolyzed as $\left[\mathrm{Al}\left(\mathrm{H}_{2} \mathrm{O}\right)_{6}\right]^{3+}$ and $\left[\mathrm{Al}(\mathrm{OH})_{4}\right]^{-}$, respectively. Additionally, the compositions with $\mathrm{pH}$ around 3-10 presented different $\left[(\mathrm{R}-\mathrm{COO})_{3} \mathrm{Al}\right],\left[(\mathrm{R}-\mathrm{COO})_{2} \mathrm{Al}\left(\mathrm{H}_{2} \mathrm{O}\right)_{2}\right]^{+}$, and $\left[(\mathrm{R}-\mathrm{COO}) \mathrm{Al}\left(\mathrm{H}_{2} \mathrm{O}\right)_{4}\right]^{2+}$ species. Considering that the gel network was formed as a metal coordination polymer based on aluminum cations-lactate interaction, the presence of a tri-lactate complex could be more efficient for the gelation process than the others. Thus, for the indicated $\mathrm{pH}$ range, partial hydrolysis of aluminum lactate could take place and the water evaporation induced during the solution's heating $\left(50-100{ }^{\circ} \mathrm{C}\right)$ led to an increase in the concentration of the tri-lactate complex, that slowly raised the liquid's viscosity until it became a gel [15].

As high alumina refractory castables usually have a $\mathrm{pH}$ range between 8 and 10 [17], the present work investigates whether the addition of different contents (0.25-1.0 wt\%) of aluminum lactate to alumina based-castables (containing calcium carbonate as sintering agent) could improve their green mechanical strength due to the gelation of this organic salt. A reference composition with $\mathrm{CAC}$ as a binder and another containing only calcium carbonate were prepared to provide a fair comparison of the refractories. The materials were analyzed based on using different techniques, such as cold and hot mechanical strength, in situ hot elastic modulus, X-ray diffraction, and apparent porosity to evaluate the binding effect after curing and drying and identify the likelihood of an earlier sintering effect associated with the selected additives at high temperatures $\left(600-1500{ }^{\circ} \mathrm{C}\right)$.

\section{EXPERIMENTAL}

Six high-alumina refractory castables (Table I) were designed based on Alfred's particle packing model and considering a distribution coefficient (q) equal to 0.26 [18], in order to obtain vibratable compositions. The selected raw materials consisted of tabular alumina $(\mathrm{d}<6 \mathrm{~mm}$, Almatis, Germany), calcined and reactive aluminas (CL370 and CT3000SG, respectively, Almatis, Germany), and calcium carbonate $\left(\mathrm{CaCO}_{3}, 99.0 \%\right.$ purity, $\mathrm{d}<6 \mu \mathrm{m}$, Labsynth, Brazil). Calcium aluminate cement (CAC, Secar 71, Imerys Aluminates, France) and aluminum lactate $(294.18 \mathrm{~g} / \mathrm{mol}$, $>98 \%$ purity, Quimibras Ind. Quím., Brazil) were evaluated as binders and the latter was added to the composition containing calcium carbonate as a sintering agent in a content of $0.25-1.0 \mathrm{wt} \%$.

During the mixing step of the refractories, distinct water contents were incorporated into the mixes (Table I), as well

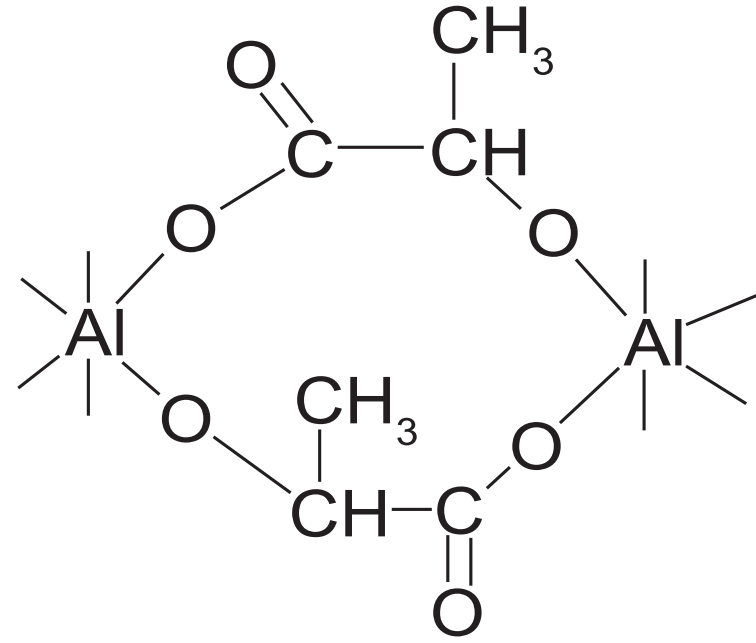

Figure 1: Schematic representation of the network formed by the aluminum lactate gel.

as $0.2 \mathrm{wt} \%$ of a polymeric dispersant (Castament FS60, BASF, Germany). The processing procedure consisted of stirring the dry-mix at $25 \mathrm{rpm}$ for $1 \mathrm{~min}$ and, after that, distilled water was constantly poured and mixed with the other components at $45 \mathrm{rpm}$ for a total of $3 \mathrm{~min}$ in a rheometer [19]. The prepared castables were molded as prismatic samples $\left(150 \times 25 \times 25 \mathrm{~mm}^{3}\right)$, which were cured at $50{ }^{\circ} \mathrm{C}$ for $24 \mathrm{~h}$ [6CAC was kept in a humid environment $(80 \%$ relative humidity)] and dried at $110{ }^{\circ} \mathrm{C}$ for another $24 \mathrm{~h}$. Cold flexural strength (3-point bending test, ASTM C133-97 standard, MTS 810 equipment, USA) and apparent porosity (ASTM C830-00 standard, using kerosene as immersion liquid) tests of the cured and dried specimens were carried out to analyze the binding effect of the additives in the prepared formulations. The sintering effect of calcium carbonate and the influence of the phase transformations in the stiffening profile of the castables was monitored via in situ hot Young's modulus (E) measurements during their first heating-cooling cycle, using the bar resonance technique (Scanelastic, ATCP, Brazil) according to ASTM C 1198-91 standard. In this test, dried samples were evaluated in the $30-1400{ }^{\circ} \mathrm{C}$ range and using a heating/cooling rate of $2{ }^{\circ} \mathrm{C} / \mathrm{min}$.

Additional samples of $6 \mathrm{CAC}, 3.2 \mathrm{CC}$, and $3.2 \mathrm{CC}-0.5 \mathrm{~L}$ were prepared and fired in the $200-1500{ }^{\circ} \mathrm{C}$ range for $5 \mathrm{~h}$. Besides cold flexural strength (ASTM C133-97) and apparent porosity (ASTM C830-00), hot modulus of rupture (HMOR) measurements were carried out to analyze the samples' behavior. HMOR tests were performed at 300 , $600,900,1200$ and $1450{ }^{\circ} \mathrm{C}$, using HBTS 422 equipment (3-point bending test, Netzsch, Germany) with specimens pre-fired for $5 \mathrm{~h}$ at the same testing temperatures or at $1500{ }^{\circ} \mathrm{C}$. Furthermore, to identify the crystalline phases generated in the cured $\left(50{ }^{\circ} \mathrm{C} / 24 \mathrm{~h}\right)$ and dried $\left(110{ }^{\circ} \mathrm{C} / 24 \mathrm{~h}\right)$ castables, as well as after the firing step at different temperatures $\left(600-1500{ }^{\circ} \mathrm{C} / 5 \mathrm{~h}\right), \mathrm{X}$-ray diffraction (XRD) measurements of the $6 \mathrm{CAC}$ and $3.2 \mathrm{CC}$ refractories' matrix fraction (fine components with $\mathrm{d}<200 \mu \mathrm{m}=$ tabular alumina $<45 \mu \mathrm{m}$, calcined and reactive aluminas, and selected additives) were 
Table I - General information about the designed compositions evaluated.

\begin{tabular}{ccccccc}
\hline Raw material (wt\%) & 6CAC & 3.2CC & 3.2CC_0.25L & 3.2CC_0.5L & 3.2CC_0.75L & 3.2CC_1L \\
\hline Tabular alumina, d<6 mm & 88.0 & 88.0 & 88.0 & 88.0 & 88.0 & 88.0 \\
Calcined alumina, CL370 & 6.0 & 6.0 & 6.0 & 6.0 & 6.0 & 6.0 \\
Reactive alumina, CT3000SG & - & 2.8 & 2.8 & 2.8 & 2.8 & 2.8 \\
Calcium aluminate cement, Secar 71 & 6.0 & - & - & - & - & - \\
Calcium carbonate & - & 3.2 & 3.2 & 3.2 & 3.2 & 3.2 \\
Aluminum lactate & - & - & 0.25 & 0.5 & 0.75 & 1.0 \\
Distilled water & 4.4 & 4.5 & 4.6 & 4.7 & 4.8 & 4.9 \\
Vibratable flow (\%) & 137 & 181 & 173 & 177 & 174 & 184 \\
Estimated CaO content (wt\%) & 1.8 & 1.8 & 1.8 & 1.8 & 1.8 & 1.8 \\
\hline
\end{tabular}

carried out in a diffractometer (D8 Focus, Bruker, Germany) with $\mathrm{CuK} \alpha$ radiation $(\lambda=1.5418 \AA$ ) and $\mathrm{Ni}$ filter, using 40 $\mathrm{mA}, 40 \mathrm{mV}$, and a scanning step of $0.02^{\circ}$. Topas software (Bruker, Germany) was used to analyze the $\mathrm{X}$-ray profiles and calculate the amount of each detected phase using the Rietveld method. The 3.2CC_0.5L castable was not analyzed as the crystalline phases generated at different temperatures were the same as in the $3.2 \mathrm{CC}$ composition.

\section{RESULTS AND DISCUSSION}

Firstly, the cold modulus of rupture and apparent porosity of $6 \mathrm{CAC}$ and $3.2 \mathrm{CC}$ castables were analyzed after curing $\left(50{ }^{\circ} \mathrm{C} / 24 \mathrm{~h}\right)$ and drying $\left(110{ }^{\circ} \mathrm{C} / 24 \mathrm{~h}\right)$ steps. Fig. 2 shows that the cement-bonded refractory presented a superior mechanical performance in both conditions, which can be explained by the formation of crystalline hydrated calcium aluminate-based phases (mainly $\mathrm{C}_{3} \mathrm{AH}_{6}$, with $\mathrm{C}=\mathrm{CaO}, \mathrm{A}=\mathrm{Al}_{2} \mathrm{O}_{3}, \mathrm{H}=\mathrm{H}_{2} \mathrm{O}$ ) and aluminum hydroxide $\left(\mathrm{AH}_{3}\right)$, as confirmed by XRD measurements and Rietveld simulations (Table II). These compounds are able to give rise to an interconnected network within the castables' matrix that is responsible for the green mechanical strength of cement-bonded refractories. The simultaneous increase of the cold modulus of rupture and apparent porosity of 6CAC after drying at $110{ }^{\circ} \mathrm{C}$ is explained by the conversion of the metastable hydrates $\left(\mathrm{C}_{2} \mathrm{AH}_{8}\right.$ and $\mathrm{AH}_{3}$ gel $)$ into the more stable ones $\left(\mathrm{C}_{3} \mathrm{AH}_{6}\right.$ and $\left.\mathrm{AH}_{3}\right)$ and by water evaporation. This conversion phenomenon also increases the porosity as the stable compounds are denser [20,21]. On the other hand, as calcium carbonate does not hydrate in the presence of water (Table II), no phase transformation involving such compound was expected to take place at the evaluated conditions and, consequently, a poor binding action of this additive resulted in low green mechanical strength for the 3.2CC samples.

Considering the limited green mechanical strength results of the calcium carbonate-bonded castable, different contents (0.25-1.0 wt \%) of aluminum lactate were added to this composition in order to analyze whether the gelation of this organic salt would improve the performance of this refractory. According to Fig. 3, the addition of aluminum lactate to $3.2 \mathrm{CC}$ castable led to a slight decrease of the samples' porosity values but no important changes in their mechanical resistance were observed after curing. Although a small addition of cement could enhance this property, the
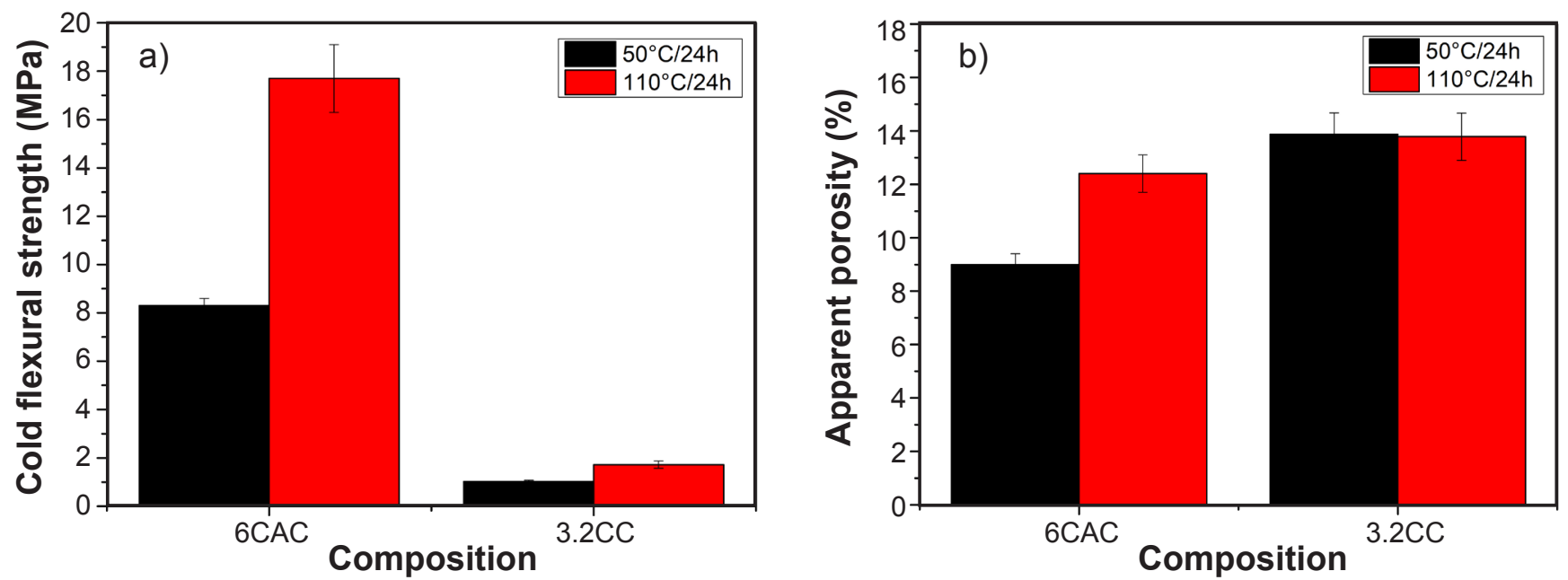

Figure 2: Cold flexural strength (a) and apparent porosity (b) of $6 \mathrm{CAC}$ and $3.2 \mathrm{CC}$ castables after curing $\left(50{ }^{\circ} \mathrm{C} / 24 \mathrm{~h}\right)$ and drying $\left(110{ }^{\circ} \mathrm{C} / 24 \mathrm{~h}\right)$ steps. 
Table II - Estimated contents (\%) of the crystalline phases comprising the matrix fraction of the dried $\left(110{ }^{\circ} \mathrm{C} / 24 \mathrm{~h}\right)$ castable samples, obtained via Rietveld simulations and XRD analyses.

\begin{tabular}{ccc}
\hline \multirow{2}{*}{ Phase } & \multicolumn{2}{c}{ Castable's matrix fraction } \\
& $6 \mathrm{CAC}$ & $3.2 \mathrm{CC}$ \\
\hline Corundum $\left(\alpha-\mathrm{Al}_{2} \mathrm{O}_{3}\right)$ & 71.14 & 88.39 \\
$\mathrm{NaAl}_{11} \mathrm{O}_{17}$ & 3.50 & 3.53 \\
$\mathrm{AH}_{3}$ & 12.64 & - \\
$\mathrm{C}_{3} \mathrm{AH}_{6}$ & 9.35 & - \\
$\mathrm{CA}_{2}$ & 3.37 & - \\
$\mathrm{CaCO}_{3}$ & - & 8.08 \\
\hline
\end{tabular}

aim of this study was to evaluate the effect of aluminum lactate only. Furthermore, Luz et al. [11] showed that cement spoils the sintering effect of calcium carbonate. After the drying step, there was a substantial increment of the cold modulus of rupture with the increase in the aluminum lactate content, and the highest value (7.5 MPa) was obtained for the mixture containing $1.0 \mathrm{wt} \%$ of this salt. Such behavior was also followed by a simultaneous increase of the samples' porosity, which is most likely related to the higher amount of water released during this step (Table I). As 3.2CC castable

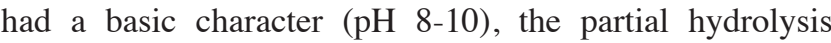
of aluminum lactate in $\left[(\mathrm{R}-\mathrm{COO})_{2} \mathrm{Al}\left(\mathrm{H}_{2} \mathrm{O}\right)_{2}\right]^{+}$and $[(\mathrm{R}-\mathrm{COO})$ $\left.\mathrm{Al}\left(\mathrm{H}_{2} \mathrm{O}\right)_{4}\right]^{2+}$ probably took place during the curing $\left(50{ }^{\circ} \mathrm{C} / 24 \mathrm{~h}\right)$ of the castables, which did not affect the cold modulus of rupture of the samples after this step. But with the increase of the temperature during drying $\left(110^{\circ} \mathrm{C} / 24 \mathrm{~h}\right)$, water was eliminated, and the concentration of the trilactate complex raised at the expense of the other lactate species [15]. This event resulted in the gelation of the salt that can be responsible for the enhancement of the samples' green mechanical strength, as the formed gel might have connected the particles' matrix. Thus, the higher aluminum lactate content induced a more effective gel formation, explaining the increasing cold modulus of rupture obtained for 3.2CC after drying (Fig. 3). Although the best results were observed for the compositions containing 1.0 and 0.75 wt $\%$ of aluminum lactate, these castables presented small cracks on their surfaces because of the expansion caused by a higher amount of gel generated. For this reason, only the composition 3.2CC_0.5L was selected for further tests.

Aiming to evaluate the sintering effect of the selected compositions (6CAC, $3.2 \mathrm{CC}$, and $3.2 \mathrm{CC} 0.5 \mathrm{~L}$ ), in situ hot elastic modulus technique was used in order to point out the temperature at which the beginning of the samples' stiffness increase would take place during their first heating treatment. The results (Fig. 4) indicated that 6CAC showed the highest initial elastic modulus (115 GPa) among the tested compositions, which was in tune with the green mechanical strength values previously discussed. While increasing the temperature, the decomposition of the hydrated phases took place in the $200-400{ }^{\circ} \mathrm{C}$ range [22],
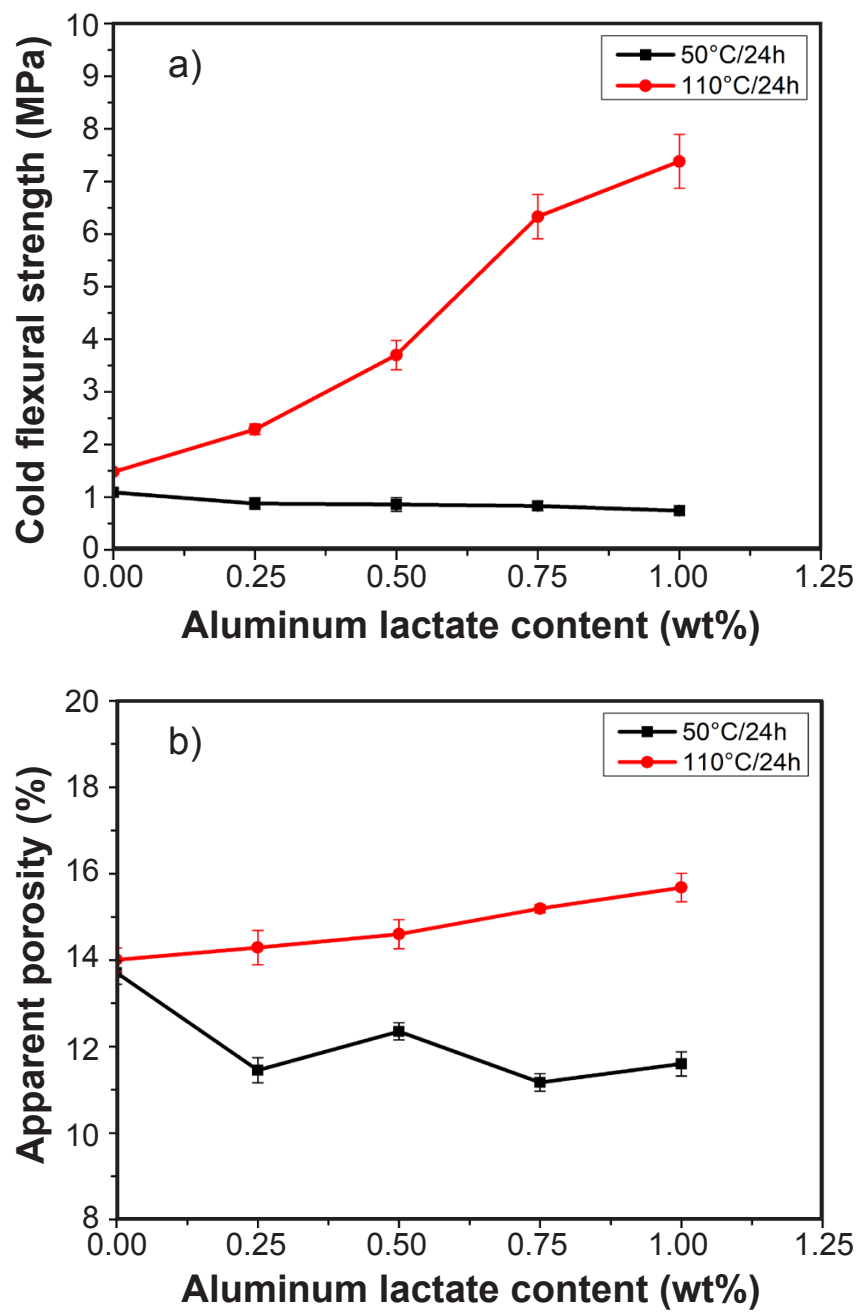

Figure 3: Cold flexural strength (a) and apparent porosity (b) of the $3.2 \mathrm{CC}$ castable containing different aluminum lactate contents (0.25-1.0 wt \% ) after curing $\left(50^{\circ} \mathrm{C} / 24 \mathrm{~h}\right)$ and drying $\left(110^{\circ} \mathrm{C} / 24 \mathrm{~h}\right)$

increasing the microstructure's porosity and causing a stiffness decay of 6CAC. After that, this castable only presented a further stiffness increase above $1000{ }^{\circ} \mathrm{C}$ due to the sintering phenomenon and the formation of calcium aluminate phases $\left(\mathrm{CA}_{2}\right.$ and $\left.\mathrm{CA}_{6}\right)$ in the refractory's matrix. The generation of these crystalline phases was confirmed by the XRD measurements and Rietveld simulations (Table III) when the refractories' matrix was analyzed after firing them at different temperatures $\left(600-1500{ }^{\circ} \mathrm{C} / 5 \mathrm{~h}\right)$. The calcium aluminate phases $\left(\mathrm{C}_{12} \mathrm{~A}_{7}, \mathrm{CA}_{2}\right.$ and $\left.\mathrm{CA}_{6}\right)$ were identified after firing the samples above $900{ }^{\circ} \mathrm{C}$. Although $\mathrm{C}_{12} \mathrm{~A}_{7}$ was not detected at $600{ }^{\circ} \mathrm{C}$, some studies [22-24] have reported that this compound can be formed in the amorphous state between 400-800 ${ }^{\circ} \mathrm{C}$ due to the cement's hydrates decomposition, but a late crystallization of this phase is expected to be detected above $800{ }^{\circ} \mathrm{C}$. Then, $\mathrm{C}_{12} \mathrm{~A}_{7}$ might also react with alumina forming $\mathrm{CA}$ in the $900-1000^{\circ} \mathrm{C}$ range, and the latter continues to react with the refractory's matrix, giving rise to the formation of $\mathrm{CA}_{2}$ between $1100-1200{ }^{\circ} \mathrm{C}$ and finally $\mathrm{CA}_{6}$ above $1300{ }^{\circ} \mathrm{C}$. During cooling, there were no further significant microstructural changes and the final elastic 


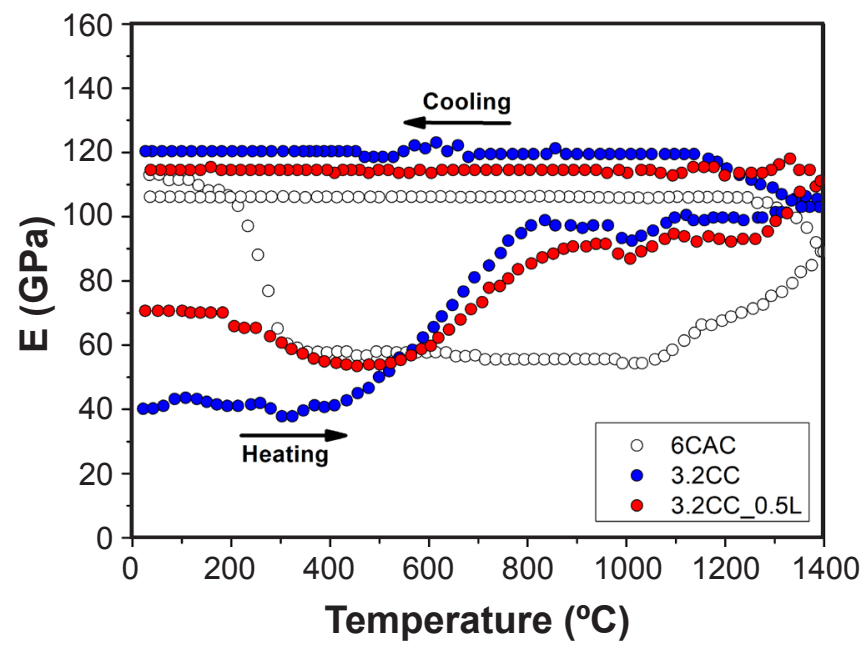

Figure 4: Young's modulus evolution as a function of temperature of $6 \mathrm{CAC}, 3.2 \mathrm{CC}$, and $3.2 \mathrm{CC} 0.5 \mathrm{~L}$ castables. The samples were cured at $50{ }^{\circ} \mathrm{C}$ for $24 \mathrm{~h}$ and dried at $110{ }^{\circ} \mathrm{C}$ for another $24 \mathrm{~h}$ before measurement.

modulus obtained for this material was around $120 \mathrm{GPa}$. Thus, the cement-bonded castables pointed out that this reference composition only presented its sintering onset close to $1000^{\circ} \mathrm{C}$.

On the other hand, 3.2CC and 3.2CC_0.5L compositions presented earlier sintering, which can be related to the SCC process derived from the action of calcium carbonate, enabling an increase in the elastic modulus of the samples between 600$800{ }^{\circ} \mathrm{C}$. As explained earlier, this process promotes a specific surface area reduction of fine calcium carbonate particles due to solid-state sintering, coarsening, and/or coalescence [12]. It is most likely that these phenomena are adding to the strengthening of the ceramic bonds, not only among the carbonate particles but also between carbonate and alumina particles of the refractories' matrix, justifying the increase in the elastic modulus at this relatively low-temperature range. Between $800-1000{ }^{\circ} \mathrm{C}$, the calcium carbonate's decomposition induced the formation of highly reactive calcium oxide $(\mathrm{CaO})$, which reacted with alumina forming $\mathrm{C}_{12} \mathrm{~A}_{7}$ and $\mathrm{CA}$ (Table III) and raised, even more, the elastic modulus of 3.2CC and 3.2CC_0.5L. Above $1000^{\circ} \mathrm{C}$, the formation of $\mathrm{CA}, \mathrm{CA}_{2}$ and $\mathrm{CA}_{6}$ (Table III) took place as mentioned for the $6 \mathrm{CAC}$ refractory. After the cooling step, the elastic modulus of 3.2CC and 3.2CC_0.5L (120 and $115 \mathrm{GPa}$, respectively) were higher than the reference composition 6CAC ( 110 GPa). However, there are two differences between refractories 3.2CC and 3.2CC_0.5L that are relevant to point out: i) the presence of the aluminum lactate gel after the drying step explains the higher initial elastic modulus of the latter (70 versus $40 \mathrm{GPa}$ ); and ii) its decomposition at $\sim 375{ }^{\circ} \mathrm{C}[14,25]$ increased the porosity content in the microstructure, causing a stiffness drop of the samples in the $300-400{ }^{\circ} \mathrm{C}$ range. Furthermore, Fig. 4 shows that this last aspect also affected the SCC process as it was delayed for the 3.2CC $0.5 \mathrm{~L}$ and also its intensity.

Fig. 5 shows the cold flexural strength and apparent porosity results of the developed castables after drying $\left(110^{\circ} \mathrm{C} / 24 \mathrm{~h}\right)$ and firing $\left(200-1500{ }^{\circ} \mathrm{C} / 5 \mathrm{~h}\right)$ steps. The cement-bonded refractory presented a mechanical resistance drop between $110-400{ }^{\circ} \mathrm{C}$ due to the increase in the samples' porosity resulting from the decomposition of the hydrates $\mathrm{C}_{3} \mathrm{AH}_{6}$ and $\mathrm{AH}_{3}$. Following this, the cold modulus of rupture of $6 \mathrm{CAC}$ increased after firing at $1000-1500{ }^{\circ} \mathrm{C}$ due to the densification promoted by the sintering phenomenon close to $1200{ }^{\circ} \mathrm{C}$. Regarding the compositions containing calcium carbonate, 3.2CC_0.5L showed a higher cold modulus of rupture than $3.2 \mathrm{CC}$ up to $600{ }^{\circ} \mathrm{C}$, when the SCC process for 3.2CC was responsible for providing better performance. Initially, the presence of the aluminum lactate-based gel seemed to reinforce the microstructure of 3.2CC_0.5L and, although the porosity increase of such samples did not cause an expressive mechanical resistance drop between $200-400{ }^{\circ} \mathrm{C}$, it was enough to disturb the SCC process. Therefore, the mechanical performance of 3.2CC_0.5L did not achieve the same level of $3.2 \mathrm{CC}$ above $800{ }^{\circ} \mathrm{C}$, even with the sintering process and the $\mathrm{CA}_{2}$ and $\mathrm{CA}_{6}$ formation taking place above $1000{ }^{\circ} \mathrm{C}$. Nonetheless, the measured cold modulus of rupture for 3.2CC_0.5 was still higher or similar to the ones of $6 \mathrm{CAC}$ between $600-1200{ }^{\circ} \mathrm{C}$.

Lastly, the results obtained for the hot modulus of rupture of the prepared castables are presented in Fig. 6. Few

Table III - Estimated content (\%) of the crystalline phases contained in the matrix fraction of the castables after firing for $5 \mathrm{~h}$ at different temperatures. The amount of the phases identified via XRD measurements were calculated based on the Rietveld method.

\begin{tabular}{cccccccccc}
\hline \multirow{2}{*}{$\begin{array}{c}\text { Matrix } \\
\text { fraction }\end{array}$} & $\begin{array}{c}\text { Firing } \\
\text { temperature }\end{array}$ & Corundum & $\mathrm{NaAl}_{11} \mathrm{O}_{7}$ & $\mathrm{CaCO}_{3}$ & $\mathrm{CaO}$ & $\mathrm{C}_{12} \mathrm{~A}_{7}$ & $\mathrm{CA}$ & $\mathrm{CA}_{2}$ & $\mathrm{CA}_{6}$ \\
\hline \multirow{6}{*}{$6 \mathrm{CAC}$} & $600{ }^{\circ} \mathrm{C}$ & 90.96 & 3.89 & - & - & - & - & - & - \\
& $900{ }^{\circ} \mathrm{C}$ & 90.19 & 3.32 & - & - & 6.50 & - & - & - \\
& $1200{ }^{\circ} \mathrm{C}$ & 76.69 & 2.22 & - & - & - & - & 21.20 & - \\
& $1500{ }^{\circ} \mathrm{C}$ & 44.45 & 1.18 & - & - & - & - & 5.11 & 49.26 \\
\hline \multirow{3}{*}{$3.2 \mathrm{CC}$} & $600{ }^{\circ} \mathrm{C}$ & 88.26 & 3.42 & 8.32 & - & - & - & - & - \\
& $900{ }^{\circ} \mathrm{C}$ & 88.96 & 2.32 & - & 1.85 & 3.33 & 3.54 & - & - \\
& $1200{ }^{\circ} \mathrm{C}$ & 72.21 & 2.39 & - & - & - & 2.01 & 23.40 & - \\
& $1500{ }^{\circ} \mathrm{C}$ & 46.48 & 0.84 & - & - & - & - & 3.22 & 49.45 \\
\hline
\end{tabular}



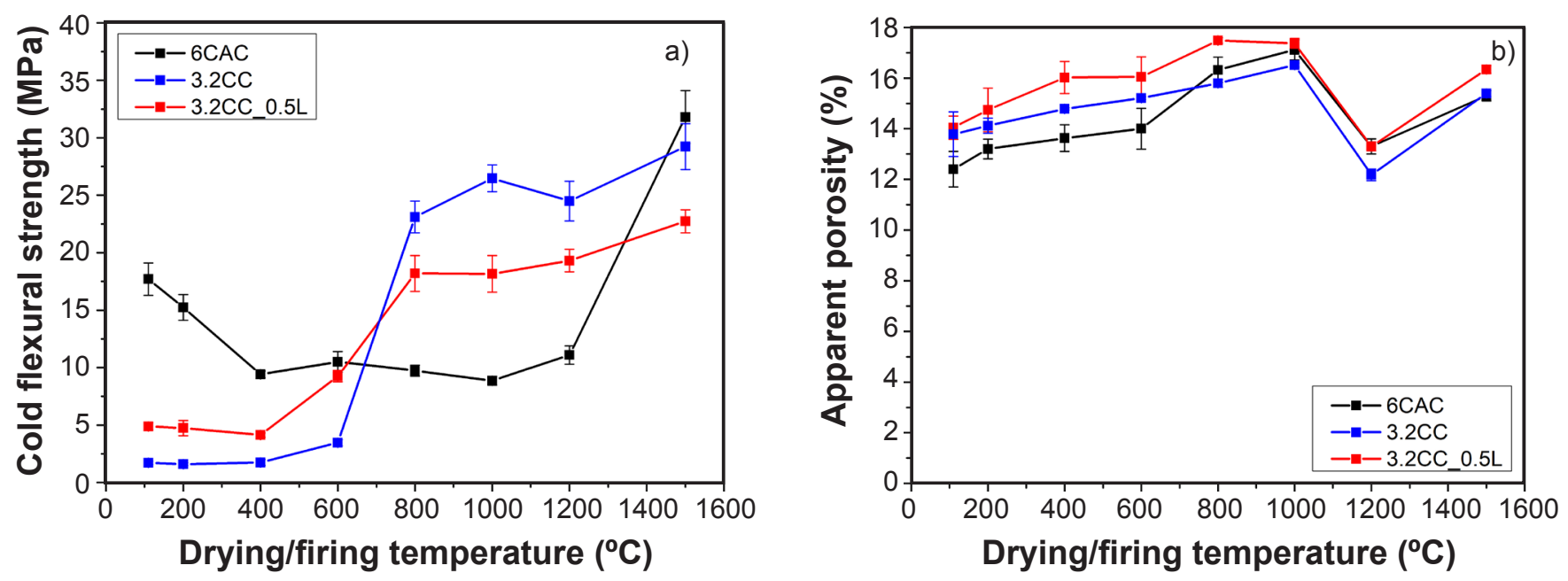

Figure 5: Cold flexural strength (a) and apparent porosity (b) of $6 \mathrm{CAC}, 3.2 \mathrm{CC}$, and $3.2 \mathrm{CC} 0.5 \mathrm{~L}$ castables after drying at $110{ }^{\circ} \mathrm{C}$ for $24 \mathrm{~h}$ and firing between 200 and $1500^{\circ} \mathrm{C}$ for $5 \mathrm{~h}$.

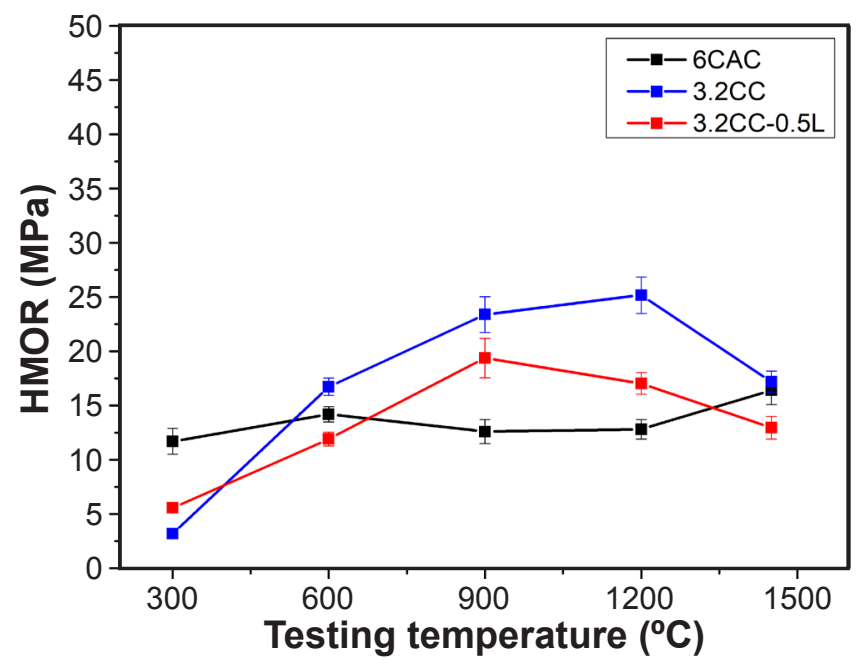

Figure 6: Hot modulus of rupture (HMOR) results of 6CAC, $3.2 \mathrm{CC}$, and $3.2 \mathrm{CC} \_0.5 \mathrm{~L}$ castables after pre-firing the samples at the same testing temperatures $\left(300-1450{ }^{\circ} \mathrm{C}\right)$ for $5 \mathrm{~h}$ before the measurements.

changes in the HMOR values obtained for 6CAC could be detected between $1200-1450{ }^{\circ} \mathrm{C}$ due to matrix densification and $\mathrm{CA}_{6}$ formation during the previous firing treatment of the prepared samples at $1500{ }^{\circ} \mathrm{C}$. On the other hand, the refractories containing calcium carbonate presented a lower hot modulus of rupture at $300{ }^{\circ} \mathrm{C}$, which was followed by a continuous increase of this property up to 900-1200 ${ }^{\circ} \mathrm{C}$. Although it was observed a drop in the HMOR values measured between $1200-1450{ }^{\circ} \mathrm{C}$, the results obtained for 3.2CC and 3.2CC_0.5L were still similar to the ones of the reference $6 \mathrm{CAC}$. Moreover, the aluminum lactate gel provided a better thermomechanical performance at 300 ${ }^{\circ} \mathrm{C}$ for 3.2CC_0.5L when compared to $3.2 \mathrm{CC}$ (5 versus 3 $\mathrm{MPa}$ ), whereas its decomposition at $\sim 375^{\circ} \mathrm{C}[14,25]$ gave rise to pores in the resulting microstructure (Fig. 5b), which affected its hot modulus of rupture at higher temperatures (600-1450 $\left.{ }^{\circ} \mathrm{C}\right)$.

\section{CONCLUSIONS}

This work investigated the addition of different contents (0.25-1.0 wt $\%)$ of aluminum lactate to alumina castables containing calcium carbonate, aiming to identify whether this additive could induce a binding effect and earlier sintering of the compositions. According to the obtained results, the cold mechanical strength of the carbonate-bonded refractory was continuously enhanced (2-7 MPa) with the increase of the aluminum lactate content, mainly after the drying $\left(110{ }^{\circ} \mathrm{C} / 24 \mathrm{~h}\right)$ of the samples. During curing $\left(50{ }^{\circ} \mathrm{C} / 24 \mathrm{~h}\right)$, the salt was hydrolyzed and no mechanical improvement was noticed, only when heated at a higher temperature the gel was formed. Nevertheless, the presence of the aluminum lactate gel improved the mechanical properties of the refractories before its decomposition between $300-400{ }^{\circ} \mathrm{C}$, and although the resulting porosity affected the sintering derived from the calcium carbonate in the $400-600^{\circ} \mathrm{C}$ range, the cold and hot modulus of rupture at $600-1500{ }^{\circ} \mathrm{C}$ were similar or even higher than the cement-bonded castable (MOR=9-22 versus $10-31 \mathrm{MPa}$ and $\mathrm{HMOR}=11-19$ versus 14-16 MPa). Therefore, as the optimum aluminum lactate content $(0.5 \mathrm{wt} \%)$ for alumina castables containing calcium carbonate was considerable low, it can be said that this organic salt induced a good binding effect after the drying step and its presence was not sufficient for spoiling the mechanical and thermomechanical properties provided by the sinteringcoarsening-coalescence (SCC) process in the refractories.

\section{ACKNOWLEDGMENTS}

This study was financed in part by the Coordenação de Aperfeiçoamento de Pessoal de Nível Superior - Brasil (CAPES) - Finance Code 001, and the Conselho Nacional de Desenvolvimento Científico e Tecnológico - Brasil (CNPq) - Process 132567/2018-0. Additionally, the authors are thankful to Almatis and to FIRE - International Federation for Refractory Research and Education. 


\section{REFERENCES}

[1] E.C. Pischke, B. Solomon, A. Wellstead, A. Acevedo, A. Eastmond, F. De Oliveira, S. Coelho, O. Lucon, Energy Res. Soc. Sci. 50 (2019) 82.

[2] A. Mele, E. Paglialunga, G. Sforna, Socio-Econ. Plan. Sci. (in press).

[3] E.A. Abdelaziz, R. Saidur, S. Mekhilef, Renew. Sustain. Energy Rev. 15 (2011) 150.

[4] L. Krietz, in "Refractories handbook", C.A. Schacht (Ed.), Marcel Dekker, Monticello (2004) 259.

[5] W.E.Lee, W. Vieira, S.Zhang, K.G.Ahari, H. Sarpoolaky, C. Parr, Int. Mater. Rev. 46 (2001) 145.

[6] J.H. Ideker, K.L. Scrivener, H. Fryda, B. Touzo, in "Lea's Chem. Cem. Concr.", $5^{\text {th }}$ ed., Butterworth-Heinemann, Oxford (2017) 537.

[7] A.P. Luz, A.B. Silva Neto, T. Santos, J. Medeiros, V.C. Pandolfelli, Ceram. Int. 39 (2013) 9063.

[8] C. Domínguez, J. Chevalier, R. Torrecillas, G. Fantozzi, J. Eur. Ceram. Soc. 21 (2001) 381.

[9] L. An, H.M. Chan, K.K. Soni, J. Mater. Sci. 31 (1996) 3223.

[10] Q. Wang, G. Ye, Y. Wang, A. Fu, C. Zhang, X. Shang, Int. J. Appl. Ceram. Technol. 12 (2015) E166.

[11] A.P. Luz, L.B. Consoni, C. Pagliosa, C.G. Aneziris, V.C. Pandolfelli, Ceram. Int. 44 (2018) 10486.

[12] P.W. Lin, P. Shen, J. Eur. Ceram. Soc. 33 (2013) 3265.
[13] S. Yeh, W. Lin, P. Liu, C. Henry, in Proc. UNITECR 2015, Viena (2015) 134.

[14] V.S. Pinto, D.S. Fini, V.C. Miguel, V.C. Pandolfelli, M.H. Moreira, T. Venâncio, A.P. Luz, Ceram. Int. 46 (2020) 11137.

[15] J. He, D. Avnir, L. Zhang, Acta Mater. 174 (2019) 418. [16] L. Zhang, C.C. de Araujo, H. Eckert, J. Non Cryst. Solids 353 (2007) 1255.

[17] A.R. Studart, V.C. Pandolfelli, E. Tervoort, L.J. Gauckler, J. Eur. Ceram. Soc. 23 (2003) 997.

[18] D.R. Dinger, J.E. Funk, Interceram 41 (1992) 95.

[19] R.G. Pileggi, A.E. Paiva, J. Gallo, V.C. Pandolfelli, Am. Ceram. Soc. Bull. 79 (2000) 54.

[20] A.P. Luz, V.C. Pandolfelli, M.A.L. Braulio, in "Refract. Castable Eng.”, Göller Verlag (2015) 157.

[21] C. Parr, F. Simonin, B. Touzo, C. Wöhrmeyer, B. Valdelièvre, A. Namba, J. Tech. Assoc. Refract. 25 (2005) 78.

[22] S. Gao, P. Zhang, N. Li, J. Zhang, J. Luan, G. Ye, G. Liao, Ceram. Int. 46 (2020) 14957.

[23] J.M. Auvray, C. Gault, M. Huger, J. Eur. Ceram. Soc. 27 (2007) 3489.

[24] Y. Wang, X. Li, B. Zhu, P. Chen, Ceram. Int. 42 (2016) 11355 .

[25] R. Venkatesh, S.R. Ramanan, J. Eur. Ceram. Soc. 20 (2000) 2543.

(Rec. 11/10/2020, Rev.09/12/2020, Ac. 16/12/2020) 